\title{
AN APPLICATION OF MACHINE LEARNING FOR ANALYSIS OF ROADWAY ACCIDENTS USING FEATURE CLASSIFICATION
}

\author{
Mr. Dharmesh Dhabliya \\ Research Analyst, Yashika Publications \\ dharmesh@yashikapublications.com \\ ORCID ID: 0000-0002-6340-2993
}

\begin{abstract}
Roadway traffic wellbeing is a significant worry for transportation overseeing organizations just as standard citizens. Data Mining is removing from concealed examples from colossal database. It is ordinarily utilized in an advertising, reconnaissance, extortion location and logical revelation. In data mining, AI is essentially engaged as exploration which is naturally figured out how to perceive complex examples and settle on smart choices dependent on data. Globalization has influenced numerous nations. There has been an intense expansion in the monetary exercises and utilization level, prompting development of movement and transportation. The increment in the vehicles, traffic lead to street accidents. Thinking about the significance of the street wellbeing, government is attempting to distinguish the reasons for street accidents to lessen the accidents level. The dramatic expansion in the accidents data is making it hard to break down the limitations causing the street accidents. The paper depicts how to mine successive examples causing street accidents from gathered data set. We discover relationship among street accidents and anticipate the kind of accidents for existing just as for new streets. We utilize affiliation and characterization rules to find the examples between street accidents and just as foresee street accidents for new streets.
\end{abstract}

Keywords: Machie Learning, Accidental Analysis Introduction

Accidents occurred because of the carelessness of driving vehicle on the streets. There are different reasons liable for the mishap like desert of traffic administers however street conditions and the traffic are viewed as the one of prime reason for casualty and causality across the globe. These accidents happen because of dynamic plan and advancement of car ventures. A car accident occurs due specific reasons like crushes of two vehicles on street, strolling individual, creature, or some other common deterrents. It could bring about injury, property harm, and passing. Car crash investigation required investigation of the different factor influencing behind them.

In review its seen that rough 1.2 million passing and 50 million wounds assessed worldwide consistently. The rough assessment of causality and wounds because of helpless street foundation is a major test before the living creatures. The request to manage the issue, in computational science, we can embrace data mining model for various situation. In any vehicle mishap, it learns about the driver's conduct, street foundation and potential outcomes of climate estimate that could be some place associated with various mishap episodes. The fundamental issue in the examination and investigation of mishap data is its blend heterogeneous climate and data division which is utilized broadly to conquer mishap issue. $[2,5,7]$

Data Mining is a computational method to manage enormous and complex data set and these data sets can be of typical, ostensible and blended. It is very simple to use in assortment of area have a place with science and the board; additionally, it very well may be utilized in misrepresentation ID and a lot more logical cases just as in mishap seriousness issue. Segment of items in a gathering of groups or in a homogeneous set is a central activity of data mining.

Clustering is a strategy to segment objects in a comparable gathering. The k-implies calculation having a decent productivity for clustering enormous data sets yet confined in framing bunches for genuine word data while working just on mathematical data since it helps in lessening the 
expense work by changing the importance of the groups $[1,3]$.

Data mining method is perceived as dependable procedure for investigation of auto collision seriousness issue and discovering factors behind them. Harm like property, individuals because of street mishap are unwanted. Ordinarily, it happened that street mishap occurrences are more normal at specific places that can help in distinguishing factors behind them. Affiliation rule mining is a procedure that recognizes the connection in various boundary of street mishap. [6]

\section{Related Work}

Accidents occurred because of the carelessness of driving vehicle on the streets. There are different reasons liable for the mishap like desert of traffic administers however street conditions and the traffic are viewed as the one of prime reason for casualty and causality across the globe. These accidents happen because of dynamic plan and advancement of car ventures. A car accident occurs due specific reasons like crushes of two vehicles on street, strolling individual, creature, or some other common deterrents. It could bring about injury, property harm, and passing. Car crash investigation required investigation of the different factor influencing behind them.

In review it's seen that rough 1.2 million passing and 50 million wounds assessed worldwide consistently. The rough assessment of causality and wounds because of helpless street foundation is a major test before the living creatures. The request to manage the issue, in computational science, we can embrace data mining model for various situation. In any vehicle mishap, it learns about the driver's conduct, street foundation and potential outcomes of climate estimate that could be some place associated with various mishap episodes. The fundamental issue in the examination and investigation of mishap data is its blend heterogeneous climate and data division which is utilized broadly to conquer mishap issue. $[2,5,7]$

Data Mining is a computational method to manage enormous and complex data set and these data sets can be of typical, ostensible and blended. It is very simple to use in assortment of area have a place with science and the board; additionally, it very well may be utilized in misrepresentation ID and a lot more logical cases just as in mishap seriousness issue. Segment of items in a gathering of groups or in a homogeneous set is a central activity of data mining.

Clustering is a strategy to segment objects in a comparable gathering. The k-implies calculation having a decent productivity for clustering enormous data sets yet confined in framing bunches for genuine word data while working just on mathematical data since it helps in lessening the expense work by changing the importance of the groups $[1,3]$.

Data mining method is perceived as dependable procedure for investigation of auto collision seriousness issue and discovering factors behind them. Harm like property, individuals because of street mishap are unwanted. Ordinarily, it happened that street mishap occurrences are more normal at specific places that can help in distinguishing factors behind them. Affiliation rule mining is a procedure that recognizes the connection in various boundary of street mishap. [6]

\begin{tabular}{|l|l|l|l|}
\hline $\begin{array}{l}\text { Text } \\
\text { Techniques }\end{array}$ & Concept & Strengths & Weakness \\
\hline Feature Selection & $\begin{array}{l}\text { A novel and efficient } \\
\text { feature selection } \\
\text { framework based on the } \\
\text { Information Theory. }\end{array}$ & $\begin{array}{l}\text { To rank the features with their } \\
\text { discriminative capacity for } \\
\text { classification. }\end{array}$ & $\begin{array}{l}\text { Complex methodology, less } \\
\text { accuracy as compared to } \\
\text { proposed. }\end{array}$ \\
\hline $\begin{array}{l}\text { Maximum } \\
\text { Discriminative }\end{array}$ & $\begin{array}{l}\text { Maximum Discriminative } \\
\text { approach for automatic text }\end{array}$ & $\begin{array}{l}\text { Unlike conventional text } \\
\text { categorization approaches, } \\
\text { proposed method selects a }\end{array}$ & $\begin{array}{l}\text { Feature selection was } \\
\text { required which was not } \\
\text { provided. Based on group } \\
\text { clustering of records. }\end{array}$ \\
\hline
\end{tabular}




\begin{tabular}{|c|c|c|c|}
\hline $\begin{array}{l}\text { Features }(\mathrm{A} \\
\text { Greedy Feature } \\
\text { Selection) }\end{array}$ & $\begin{array}{l}\text { categorization using class- } \\
\text { specific features }\end{array}$ & $\begin{array}{l}\text { specific feature subset for } \\
\text { each class. }\end{array}$ & $\begin{array}{l}\text { Feature selection issues } \\
\text { provided less accuracy. }\end{array}$ \\
\hline $\begin{array}{l}\text { Text } \\
\text { Classification } \\
\text { Process }\end{array}$ & $\begin{array}{l}\text { Proposed combination } \\
\text { different classification } \\
\text { algorithms for text } \\
\text { categorization. }\end{array}$ & $\begin{array}{l}\text { Good detailing was provided } \\
\text { for individual techniques. } \\
\text { Hybrid technique were first } \\
\text { time proposed in systems. }\end{array}$ & $\begin{array}{l}\text { Comparison less. } \\
\text { Parameters was more to time } \\
\text { and it was Complex } \\
\text { implement require more } \\
\text { Clustering Techniques } \\
\text { provided. }\end{array}$ \\
\hline $\begin{array}{l}\text { Naïve Bayes } \\
\text { Classifiers }\end{array}$ & $\begin{array}{l}\text { The hypothesis and routine } \\
\text { of two distinctive first } \\
\text { arrange probabilistic } \\
\text { classifiers, both of which } \\
\text { made the guileless Bayes } \\
\text { supposition. }\end{array}$ & $\begin{array}{l}\text { The multinomial model was } \\
\text { observed to be consistently } \\
\text { superior to the multi variant } \\
\text { Bernoulli display. }\end{array}$ & $\begin{array}{l}\text { As compare to proposed } \\
\text { Naïve Bayes result was } \\
\text { proper. Content oriented } \\
\text { with basic advancements in } \\
\text { text mining, but no } \\
\text { methodologies were } \\
\text { provided. }\end{array}$ \\
\hline KNN Classifier & $\begin{array}{l}\text { Proposed modified KNN } \\
\text { classification algorithms } \\
\text { for text categorization. }\end{array}$ & $\begin{array}{l}\text { Modified KNN algorithm was } \\
\text { less complex as compared to } \\
\text { existing one. Nice explanation } \\
\text { of points based on content } \\
\text { mining with unstructured and } \\
\text { semi structured data. }\end{array}$ & $\begin{array}{l}\text { As compared to Naïve Bayes } \\
\text { result are proper. Only } \\
\text { content information was } \\
\text { provided. No methodologies } \\
\text { were given. }\end{array}$ \\
\hline
\end{tabular}

\section{Proposed Approach}

The strategy incorporate data preprocessing and clustering utilizing k-implies calculation. The clustering and order methods will be utilized for data preprocessing and afterward for examination of street mishap in the year 2016 for different boundaries like street type, sex, month to month investigation, age, sort of vehicle and so onThe proposed work is planned to be carried out in the following manner.

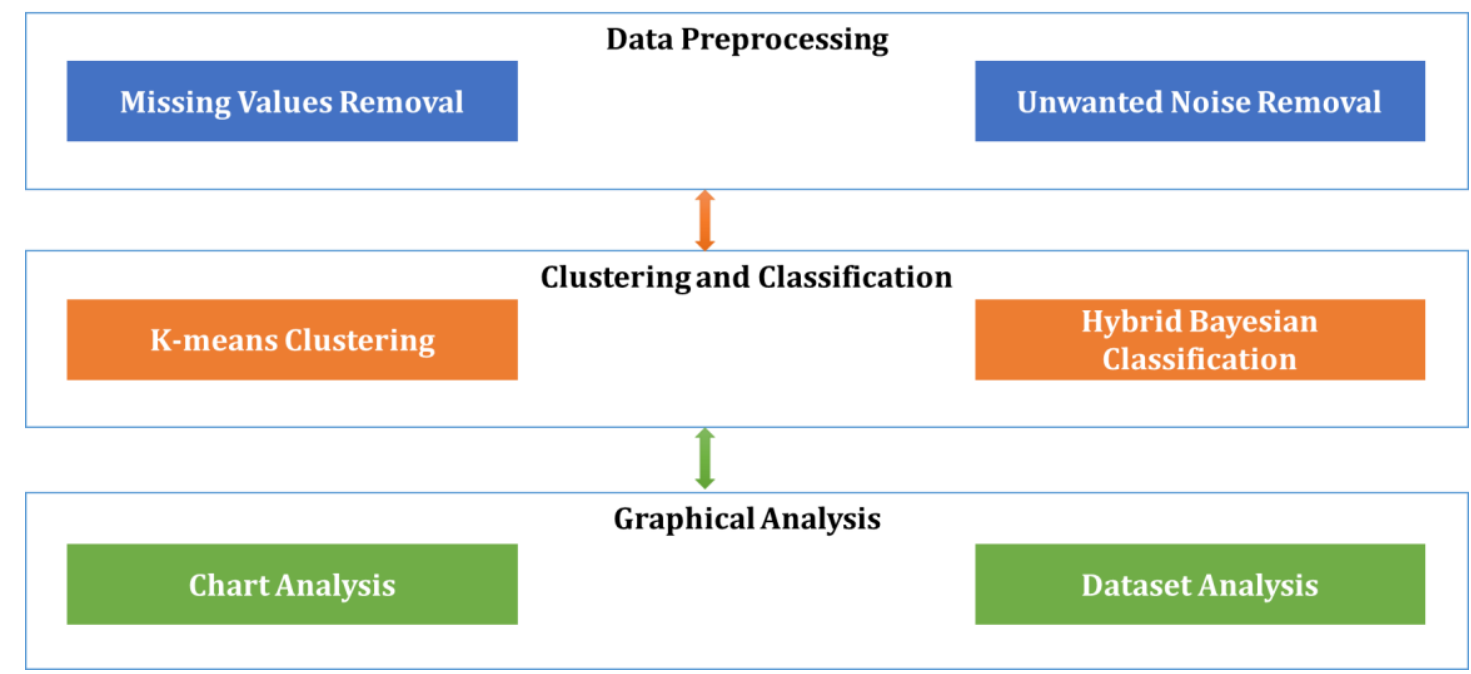

Fig: Proposed Methodology 


\section{Results and Discussion}

\section{Graph Analysis for different parameters}

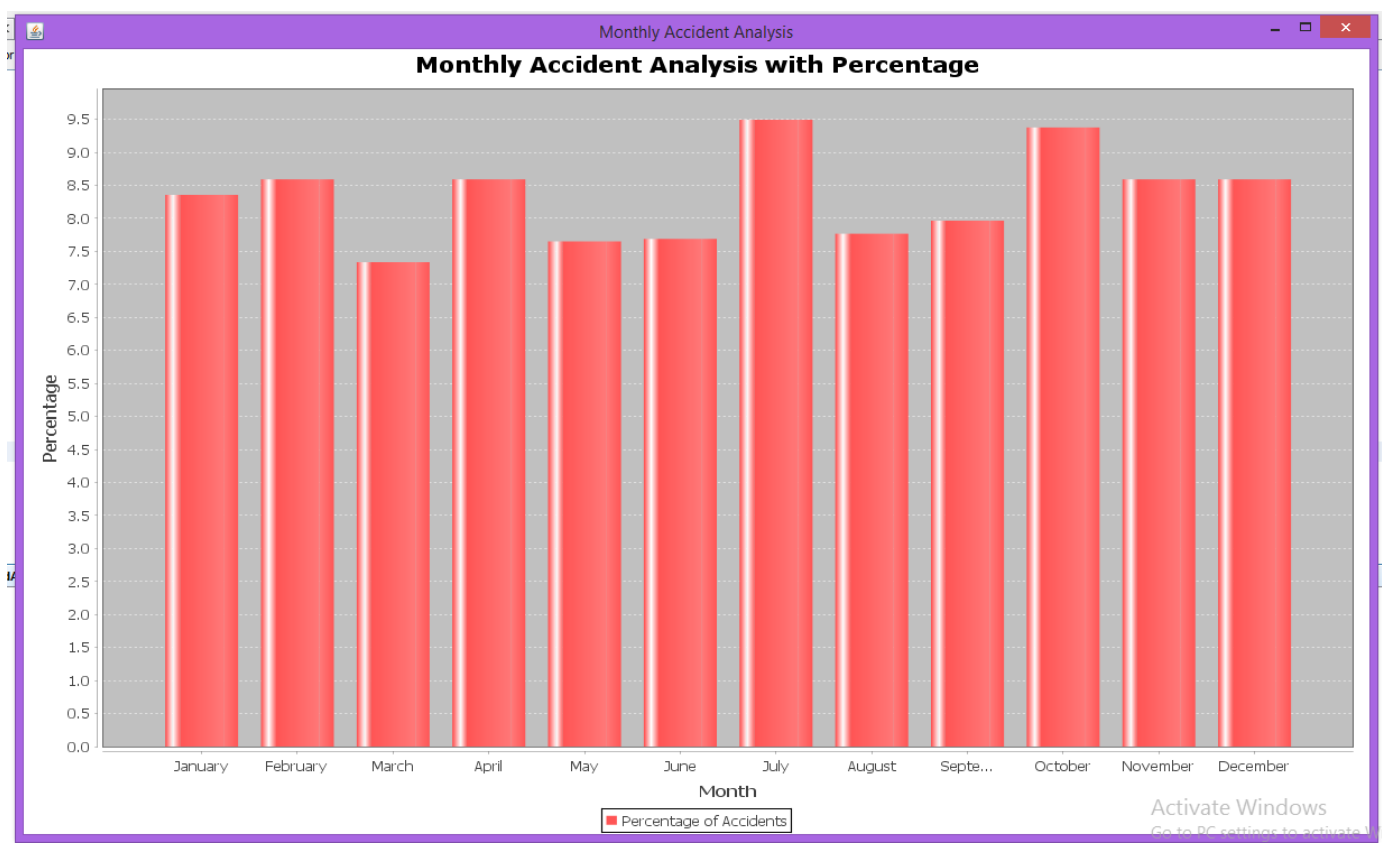

Figure: Monthly Analysis for number of Accidents

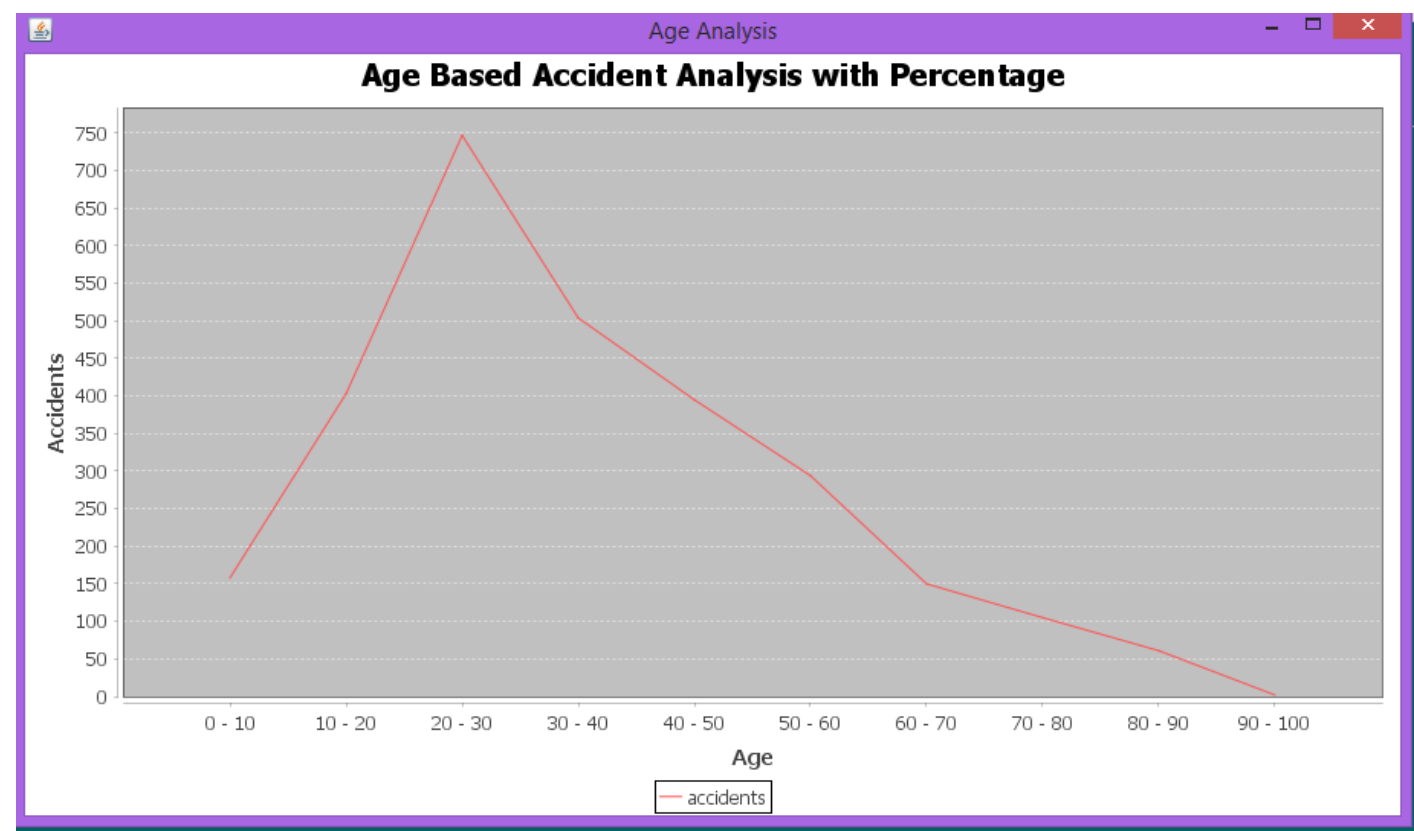

Figure: Age Based Analysis 


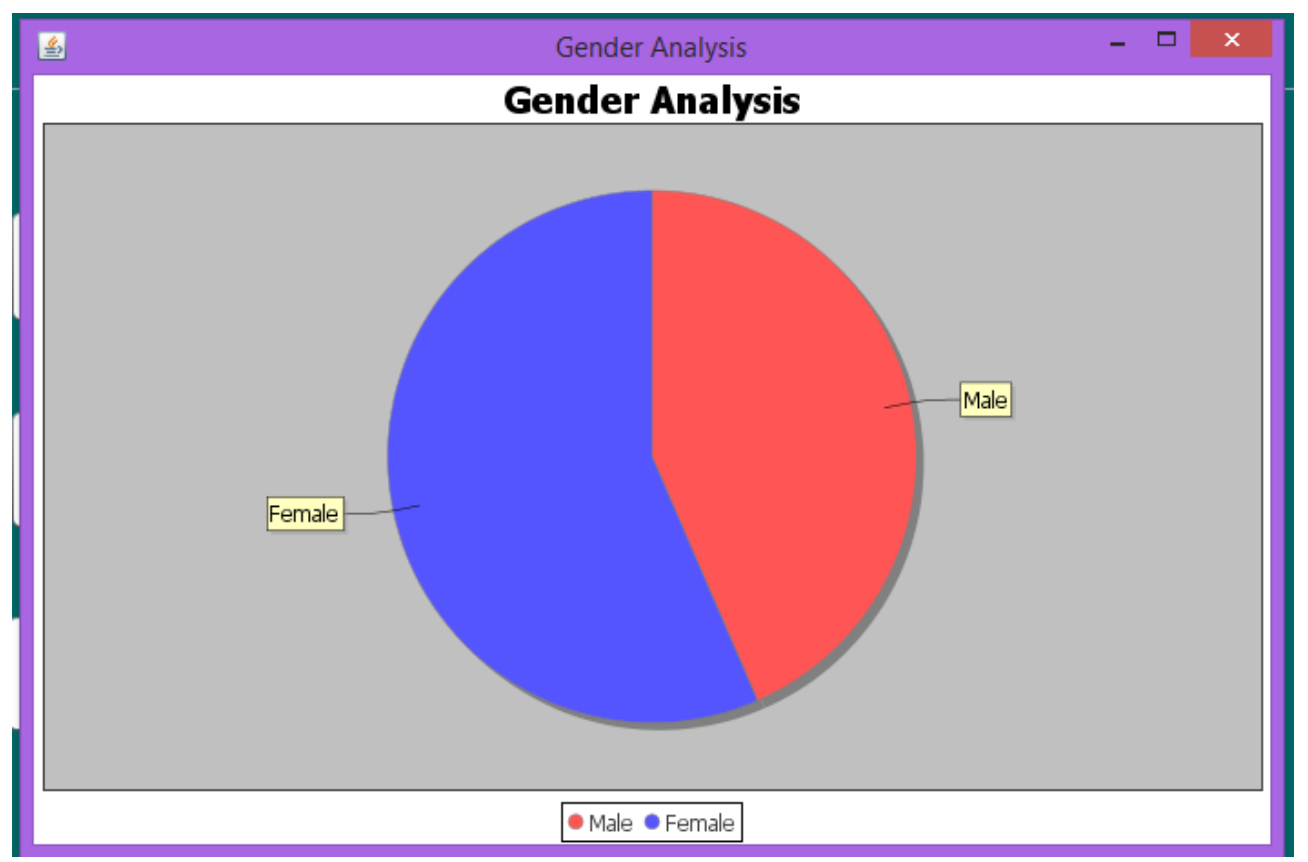

Figure: Gender Based Analysis

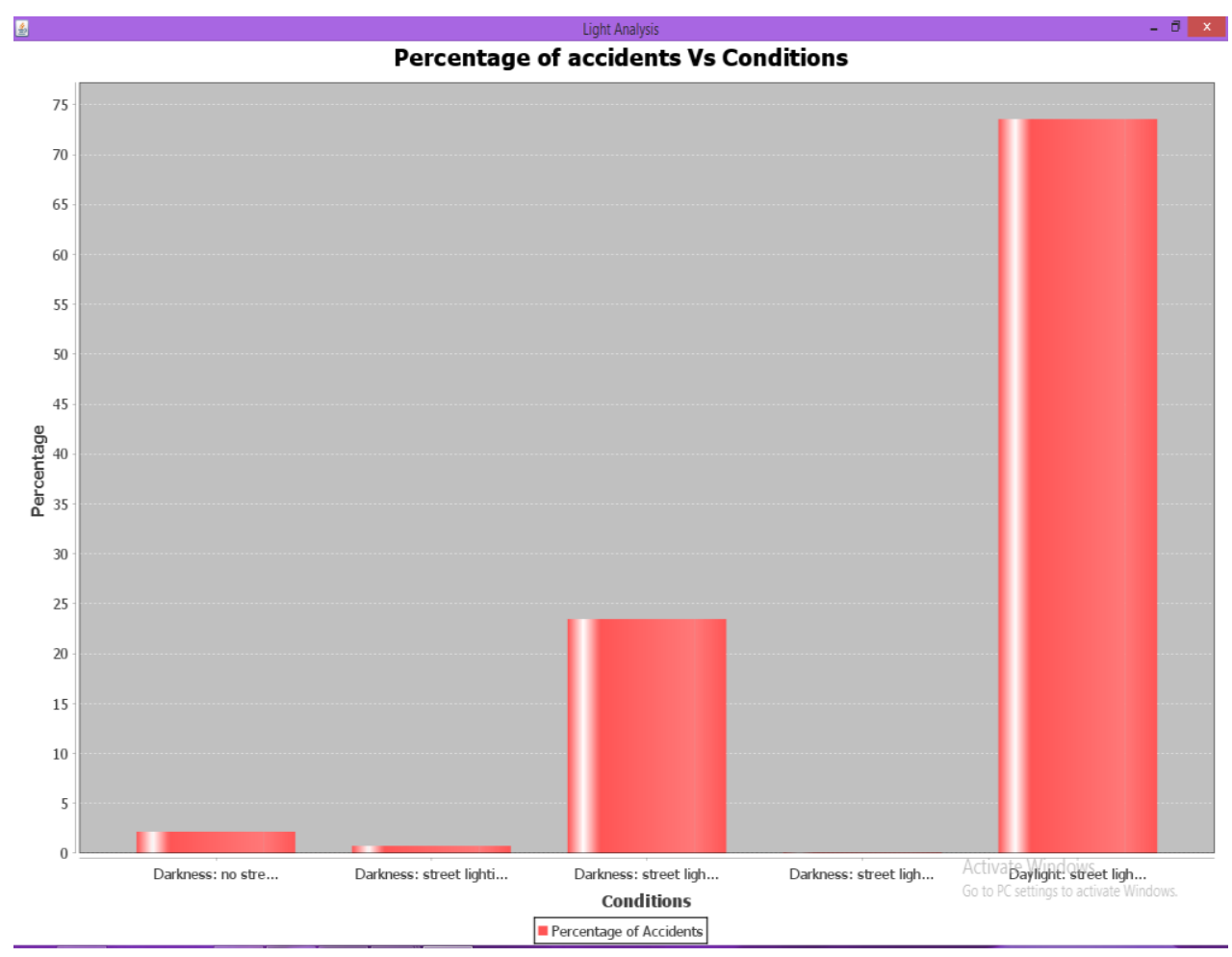

Figure: Number of Accidents categorized by Light Conditions 


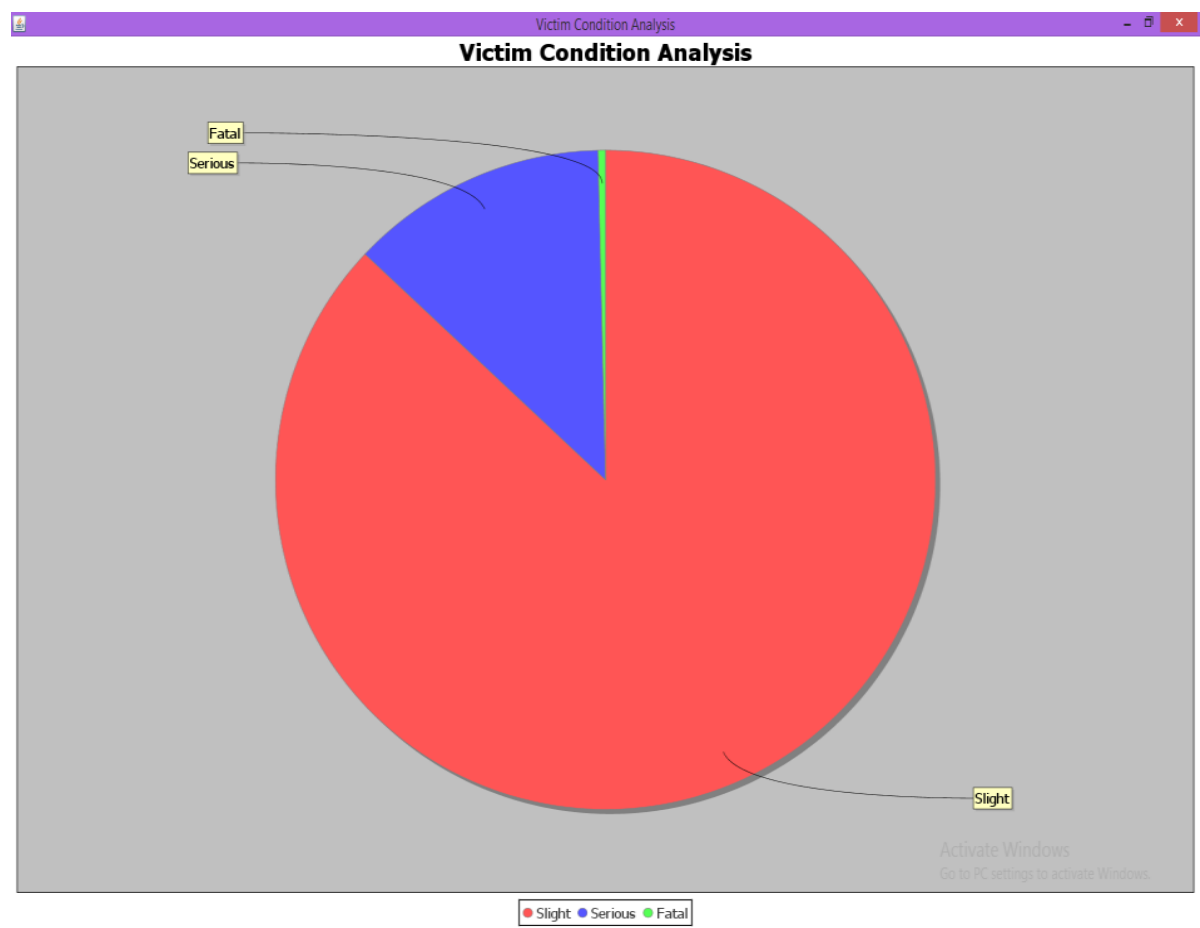

Figure 5: Victim Condition Analysis

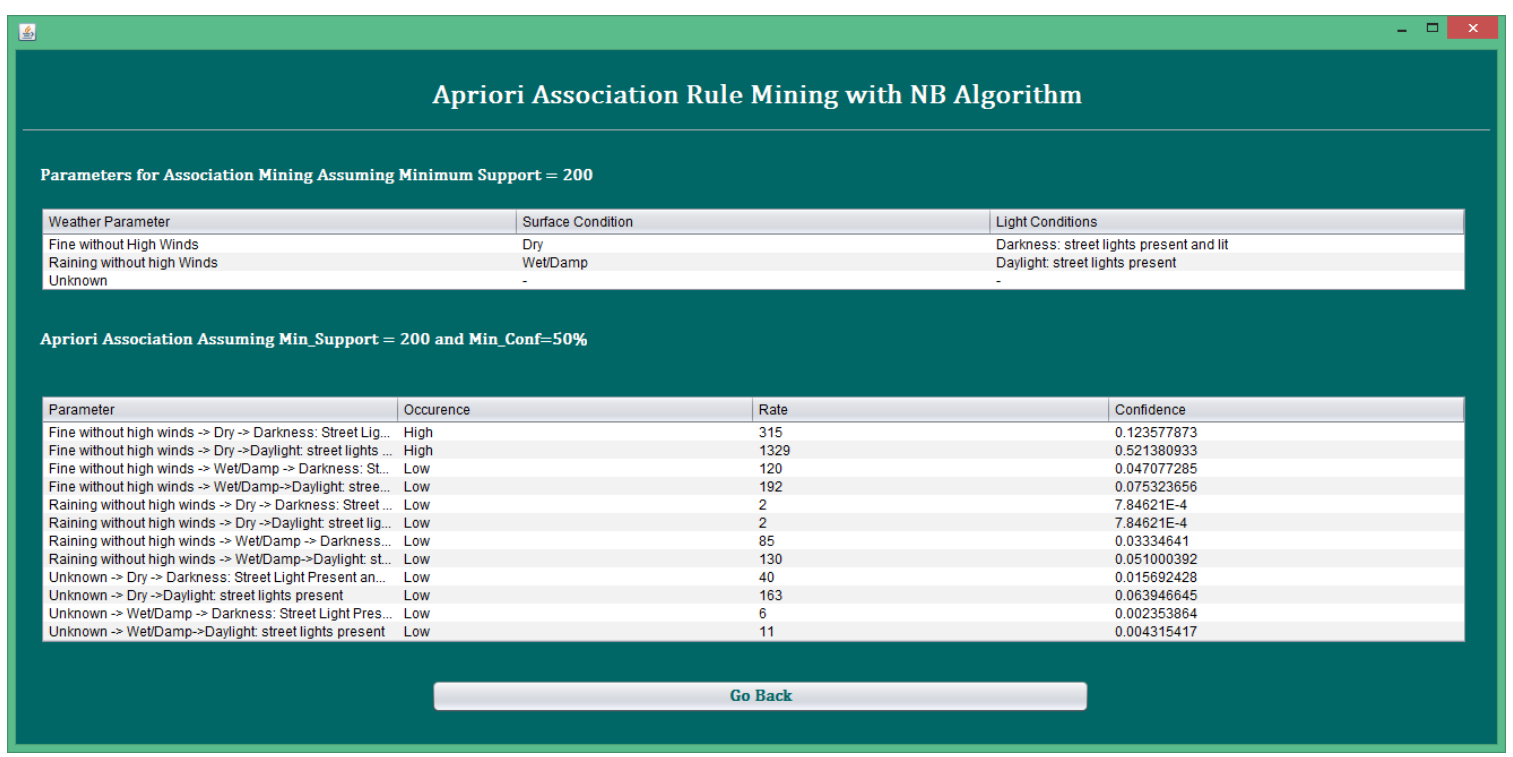

Figure: Results after applying Apriori Algorithm

\section{CONCLUSION AND FUTURE WORK}

\section{Conclusion}

There has been a radical expansion in the financial exercises and utilization level, prompting extension of movement and transportation. The expansion in the vehicles, traffic lead to street accidents. Thinking about the significance of the street wellbeing, government is attempting to distinguish the reasons for street accidents to lessen the accidents level. We have given a concise unplanned examination on UK dataset of year 2016. Utilizing different boundaries we have produced affiliation mining rules and preprocessed dataset as needs be. We have additionally extricated brings about type of diagrams utilizing Java Freechart API. Utilizing proposed framework it is not difficult to examine reasons of accidents with its most likely conditions. 


\section{Future Work}

In future we can additionally upgrade the framework by gave investigation of numerous long periods of dataset for a particular country so the mishap proportion can be seen with enhancements. Additionally we can work on investigating country insightful outcomes dependent on region of country and populace rate.

\section{References}

[1] Zhexue Huang, "Extensions to the k-Means Algorithm for Clustering Large Data Sets with Categorical Values", Data Mining and Knowledge Discovery 2, 283-304 (1998).

[2] Sachin Kumar and Durga Toshniwal, "A data mining framework to analyse road accident data", Journal of Big Data (2015) 2:26 DOI 10.1186/s40537-015-0035-y.

[3] S. Krishnavenians Dr. M. Hemalatha, "A perspective analysis of Traffic Accident Using Data Mining Techniques", International Journal of Computer Application.

[4] Sachin Kumar and Durga Toshniwal, "A data mining approach to characterize road accident locations", J. Mod. Transport. (2016) 24(1):62-72 DOI 10.1007/s40534016- 0095-5.

[5] Dharmesh Dhabliya, Dr.S.A.Sivakumar. (2019). Analysis and Design of Universal Shift Register Using Pulsed Latches . International Journal of New Practices in Management and Engineering, 8(03), 10 16.

https://doi.org/10.17762/ijnpme.v8i03.78

[6] Tibebe Beshah, Shawndra Hill, "Mining Road Traffic Accident Data to Improve Safety: Role of Road- elated Factors on Accident Severity in Ethiopia"

[7] Mr. Dharmesh Dhabliya, Prof. Ojaswini Ghodkande. (2016). Prevention of Emulation Attack in Cognitive Radio Networks Using Integrated Authentication . International Journal of New Practices in Management and Engineering, 5(04), 06 11. Retrieved from http://ijnpme.org/index.php/IJNPME/articl e/view/48

[8] Quinlan, J. R. C4.5: Programs for Machine Learning. Morgan Kaufmann Publishers, 1993.
[9] K. Jayasudha and Dr. C. Chandrasekar, "An overview of Data Mining in Road Traffic and Accident Analysis", Journal of Computer Applications, Vol - II, No.4, Oct - Dec 2009.

[10] Miao Chong, Ajith Abraham and Marcin Paprzycki, "Traffic Accident Analysis Using Machine Learning Paradigms", Informatica 29 (2005) 89-98.

[11] Sameer A. Agrawal, Ashish M. Umbarkar, Nitin P. Sherie, Ashish M. Dharme, Dharmesh Dhabliya, Statistical study of mechanical properties for corn fiber with reinforced of polypropylene fiber matrix composite, Materials Today: Proceedings,2021, ISSN 2214-7853, https://doi.org/10.1016/j.matpr.2020.12.10 72.

[12] M. Sowmya and Dr.P. Ponmuthuramalingam, "Analyzing the Road Traffic and Accidents with Classification Techniques", International Journal of Computer Trends and Technology (IJCTT) - volume 5 number 4 -Nov 2013.

[13] Mr. Ashish Uplenchwar. (2017). Modern Speech Identification Model using Acoustic Neural approach . International Journal of New Practices in Management and Engineering, 6(03), 01 - 06. https://doi.org/10.17762/ijnpme.v6i03.58

[14] Prof. Shweta Jain. (2017). Design and Analysis of Low Power Hybrid Braun Multiplier using Ladner Fischer Adder. International Journal of New Practices in Management and Engineering, 6(03), 07 12.

https://doi.org/10.17762/ijnpme.v6i03.59

[15] Prof. Bhushan Thakre, Dr. R.M Thakre. (2017). Analysis of Modified Current Controller and its Implementation in Automotive LED. International Journal of New Practices in Management and Engineering, 6(04), $01 \quad-\quad 06$. https://doi.org/10.17762/ijnpme.v6i04.60

[16] Prof. Deepanita Mondal. (2018). Analysis and Evaluation of MAC Operators for Fast Fourier Transformation. International Journal of New Practices in Management and Engineering, 7(01), $01 \quad-07$. https://doi.org/10.17762/ijnpme.v7i01.62 
[17] Prof. Arun Pawar, Mr. Dharmesh Dhabliya. (2018). Intelligent Modulation Recognition System and its Implementation using MATLAB. International Journal of New Practices in Management and Engineering, 7(01), 08 14. https://doi.org/10.17762/ijnpme.v7i01.63

[18] Prof. Barry Wiling. (2018). Identification of Mouth Cancer laceration Using Machine Learning Approach. International Journal of New Practices in Management and Engineering, 7(03), $01 \quad-\quad 07$. https://doi.org/10.17762/ijnpme.v7i03.66

[19] Prof. Vaishali Sarangpure. (2018). Hybrid Hand-off Scheme for Performance Improvisation of Wireless Networks. International Journal of New Practices in Management and Engineering, 7(03), 08 14. https://doi.org/10.17762/ijnpme.v7i03.67

[20] Prof. Amruta Bijwar, Prof. Madhuri Zambre. (2018). Voltage Protection and Harmonics Cancellation in Low Voltage Distribution Network. International Journal of New Practices in Management and Engineering, 7(04), 01 - 07. https://doi.org/10.17762/ijnpme.v7i04.68
[21] Mr. Rahul Sharma. (2018). Monitoring of Drainage System in Urban Using Device Free Localization Neural Networks and Cloud computing. International Journal of New Practices in Management and Engineering, 7(04), $08 \quad$ - 14. https://doi.org/10.17762/ijnpme.v7i04.69

[22] Mr. A. Kingsly Jabakumar. (2019). Enhanced QoS and QoE Support through Energy Efficient Handover Algorithm for UMTS Architectures. International Journal of New Practices in Management and Engineering, $8(01), \quad 01 \quad-\quad 07$. https://doi.org/10.17762/ijnpme.v8i01.73

[23] Olutayo V.A and Eludire A.A, "Traffic Accident Analysis Using Decision Trees and Neural Networks", I.J. Information Technology and Computer Science, 2014, 02, 22-28 Published Online January 2014 in MECS (http://www.mecs-press.org/) DOI: $10.5815 /$ ijitcs. 2014.02.03.

[24] K. Geetha and C. Vaishnavi, "Analysis on Traffic Accident Injury Level Using Classification", International Journal of Advanced Research in Computer Science and Software Engineering, Volume 5, Issue 2, February 2015, ISSN: 2277 128X. 